\title{
Dual enzyme activated fluorescein based fluorescent probe
}

\author{
Maria L. Odyniec ${ }^{1}$, Jordan E. Gardiner ${ }^{1}$, Adam C. Sedgwick ${ }^{1,2}$, Xiao-Peng He ${ }^{3}$, Steven D. Bull (凶) ${ }^{1}$, \\ Tony D. James (凶) ${ }^{1}$ \\ 1 Department of Chemistry, University of Bath, Bath, BA2 7AY, UK \\ 2 Department of Chemistry, University of Texas at Austin, Austin, TX 78712-1224, USA \\ 3 Key Laboratory for Advanced Materials \& Feringa Nobel Prize Scientist Joint Research Center, East China University of Science and Technology, \\ Shanghai 200237, China
}

(C) The Author(s) 2019. This article is published with open access at link.springer.com and journal.hep.com.cn

\begin{abstract}
A simple dual analyte fluorescein-based probe (PF3-GIc) was synthesised containing $\beta$-glucosidase $(\beta$ glc) and hydrogen peroxide $\left(\mathrm{H}_{2} \mathrm{O}_{2}\right)$ trigger units. The presence of $\beta$-glc, resulted in fragmentation of the parent molecule releasing glucose and the slightly fluorescent mono-boronate fluorescein (PF3). Subsequently, in the presence of glucose oxidase (GOx), the released glucose was catalytically converted to D-glucono- $\delta$-lactone, which produced $\mathrm{H}_{2} \mathrm{O}_{2}$ as a by-product. The $\mathrm{GOx}$-produced $\mathrm{H}_{2} \mathrm{O}_{2}$, resulted in classic $\mathrm{H}_{2} \mathrm{O}_{2}$-mediated boronate oxidation and the release of the highly emissive fluorophore, fluorescein. This unique cascade reaction lead to an 80 -fold increase in fluorescence intensity.
\end{abstract}

Keywords chemosensors, dual-activation, GOx, fluorescence, $\beta$-glucosidase, molecular logic

\section{Introduction}

Glucose is an essential source of fuel for all cells in the body for use in metabolic pathways. Despite its necessity in everyday life, it is implicated in a wide range of diseases, including diabetes, Alzheimer's and cancer. The role of glucose in cancer and Alzheimer's disease development has only recently started to be understood. In all cancer cells there is an increased need for glycolysis and glucose uptake for ATP production; corresponding to overexpression of glucose transporter protein (GLUT and SGLT) which promote cancer cell proliferation [1]. Recent research has also indicated that lower rates of glycolysis and downregulated expression of the same glucose

Received August 15, 2018; accepted October 17, 2018

E-mails: S.D.Bull@bath.ac.uk (Bull S D), T.D.James@bath.ac.uk (James T D) transport proteins combined with higher brain glucose levels correlate to enhanced $\beta$-amyloid plaque formation in Alzheimer's patients. This causes further neurodegeneration and increased expression of disease symptoms, including memory loss and impaired cognitive function $[2,3]$.

$\beta$-Glucosidases $(\beta$-glc) catalyse the hydrolysis of glycosidic bonds with the release of glucose. The enzyme is a powerful tool for degredation of cellulose in plant cell walls [4]. In addition, $\beta$-glc has been identified as a target critically involved with breast cancer growth and chemoreistance. Lui et al. have shown that $\beta$-glc inhibition suppressed growth of breast cancer cells and significantly sensitised breast cancer cells to chemotherapy [5]. Targeting $\beta$-glc is emerging as a possible therapeutic stategy in the treatment of breast cancers which are resistant to a single chemotherapeutic agent alone.

Glucose oxidase (GOx) is known to catalyse the oxidation of glucose to D-glucono- $\delta$-lactone, producing hydrogen peroxide $\left(\mathrm{H}_{2} \mathrm{O}_{2}\right)$ as a by-product. The primary function of $\mathrm{GOx}$ is as a defence mechanism in fungi and insects, where the $\mathrm{H}_{2} \mathrm{O}_{2}$ produced is used to kill bacteria [6]. In this work, we set out to develop a unique reactionbased fluorescent probe capable of monitoring the activity of $\beta$-glc through exploiting the close relationship between GOx, glucose and the generation of $\mathrm{H}_{2} \mathrm{O}_{2}$. GOx is widely used in biosensors as a molecular diagnostic tool to detect glucose levels in biological fluids [7].

Quantitative measurement of $\mathrm{H}_{2} \mathrm{O}_{2}$, correlates with the level of GOx present in the system. As $\mathrm{H}_{2} \mathrm{O}_{2}$ cannot be visualised directly in vitro, it is often used as an analyte towards reaction-based fluorescence probes producing a fluorescent product. Many fluorescent sensors have been developed for the detection of $\mathrm{H}_{2} \mathrm{O}_{2}$; see reviews by Chang et al. and James et al. [8,9]. $\mathrm{H}_{2} \mathrm{O}_{2}$ is a highly reactive oxygen species (ROS), generated through controlled physiological processes. $\mathrm{H}_{2} \mathrm{O}_{2}$ is a by-product of catalytic 
activity in the mitochondria and protein folding in the endoplasmic reticulum. However, $\mathrm{H}_{2} \mathrm{O}_{2}$ can become deleterious when cells are under oxidative stress, as levels are elevated and can cause irreversible cellular damage via oxidation of biomolecules $[10,11]$.

There are limited examples of fluorescence-based probes which utilise in situ generation of $\mathrm{H}_{2} \mathrm{O}_{2}$ by GOx to produce a fluorescence response. Most notable is the Amplex Red enzyme assay (Available from ThermoFisher.com), which requires the peroxidase enzyme to produce a fluorescent adduct $[12,13]$. While previous probes designed to detect GOx activity in the literature, have glucose in the system as an external additive [14].

Fluorescein derivatives are some of the most common fluorescent reagents for biological research, because of the excellent fluorescence quantum yield of the fluorescein and good water solubility. The fluorescein motif allows for dual-activated sensor systems as it has two free phenolic alcohols which can be derivatised independently, as illustrated by James et al. [15]. Therefore, in this work, we have used a similar strategy by incorporating glucose onto the mono-boronate fluorescein, PF3 [16] to form PF3-Glc. PF3-Glc was able to undergo a unique reaction cascade, in which glucose is generated as a product of a reaction between PF3-Glc and $\beta$-glc. In turn, the glucose reacts with $\mathrm{GOx}$ to produce $\mathrm{H}_{2} \mathrm{O}_{2}$, which results in the formation of highly fluorescent fluorescein through $\mathrm{H}_{2} \mathrm{O}_{2}$ mediated oxidation of the boronate ester (Scheme 1).

\section{Results and discussion}

PF3-Glc was readily synthesised in four steps (Scheme 2).
Fluorescein was triflated using $\mathrm{N}$-phenyl bis(trifluoromethanesulfonamide), to afford fluorescein mono-triflate [17]. A Koenigs-Knorr glycosylation reaction was then carried out to selectively form the $\beta$-glycosidic bond with the per-acetylated sugar. Followed by a Suzuki-Miyaura borylation cross coupling, to introduce the boronate ester group. The final step was an acetate deprotection using catalytic sodium methoxide. Under these conditions PF3Glc was prepared in an overall yield of $10 \%$.

With PF3-Glc in hand, fluorescence studies were undertaken. PF3-Glc is initially non-fluorescent; the probes spectral properties were investigated in different solvent systems (see ESI Figs. S1 and S2). We find that there is a small fluorescence response in dimethyl sulfoxide, methanol and water, with little change in the ultra-violet-visible spectra. We chose to undertake all further experiments in phosphate buffered saline (PBS) to mimic a biological system. On the addition of CelTec2 $(0.5 \mathrm{U})$, a commercially available enzyme blend known to contain $\beta$-glc, there was a small increase in fluorescence intensity after one-hour incubation (Fig. 1). This fluorescence increase was consistent with the generation of monofunctionalised fluorescein probes [15-17]. Incremental additions of GOx resulted in a much larger increase in fluorescence intensity. The fluorescent spectra were collected after $1.5 \mathrm{~h}$ incubation with both enzymes. When the sensor was incubated with GOx only, no turn on fluorescence response was observed after one hour. This clearly demonstrated that the $\beta$-glc enzyme cleaves a molecule of glucose to act as a substrate for GOx, which in turn produces $\mathrm{H}_{2} \mathrm{O}_{2}$ in situ to oxidise the boronate ester to the corresponding phenol. Both enzymes show no autofluoresence in the buffered system (PBS buffer, $\mathrm{pH}=$

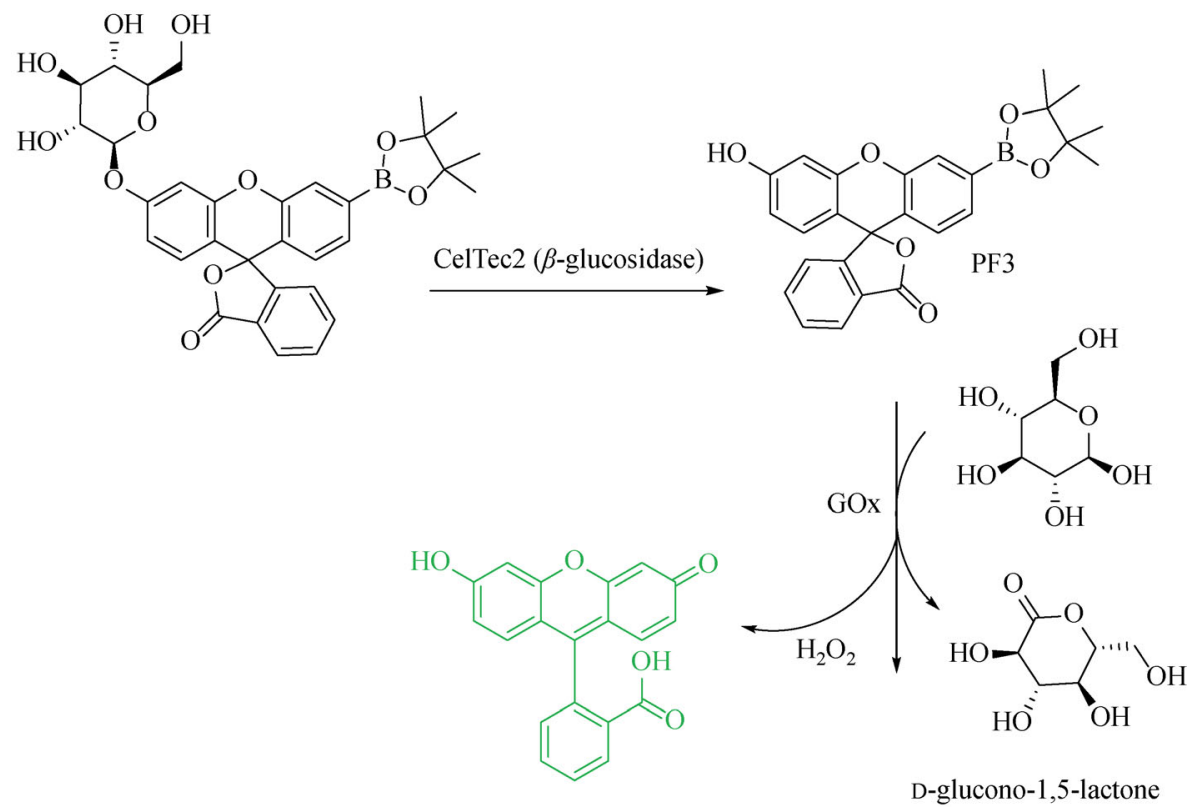

Scheme 1 Structure of PF3-Glc/PF3 and the proposed sensing mechanism for sequential detection of $\beta$-glc and $\mathrm{H}_{2} \mathrm{O}_{2}$ 


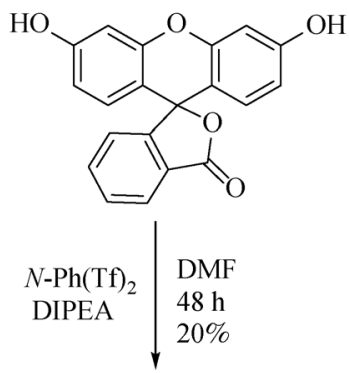

$\mathrm{TfO}$<smiles>Cc1ccc2c(c1)Oc1cc(O)ccc1C21OC(=O)c2ccccc21</smiles>

\section{$\mathrm{H}$}<smiles>CC(=O)OC[C@H]1O[C@H](Br)[C@@H](OC(C)=O)[C@H](OC(C)=O)[C@@H]1OC(=O)OC[C@H]1O[C@H](Oc2ccc3c(c2)Oc2cc(O)ccc2C32OC(=O)c3ccccc32)[C@H](OC(C)=O)[C@@H](OC(C)=O)[C@@H]1OC(C)=O</smiles><smiles>CC1(C)OB(c2ccc3c(c2)Oc2cc(O[C@@H]4O[C@H](CO)[C@@H](O)[C@H](O)C4O)ccc2C32OC(=O)c3ccccc32)OC1(C)C</smiles>

$\mathrm{NaOMe}$

$\mathrm{MeOH}, \mathrm{rt}$ $1 \mathrm{~h}, 94 \%$

Scheme 2 Synthesis of PF3-Glc

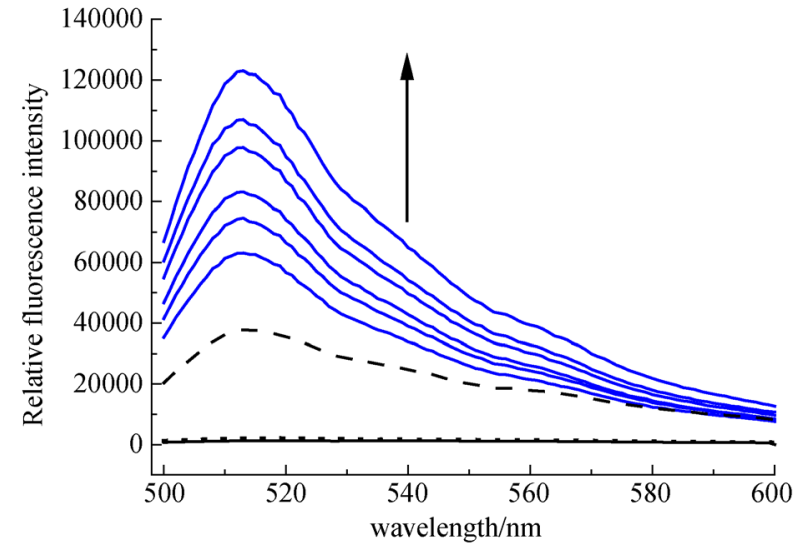

Fig. 1 Fluorescence spectra of PF3-Glc $(500 \mathrm{nmol} / \mathrm{L})$ with titration of GOx $(1,2,4,6,8,10 \mathrm{U}$, blue lines) in the presence of CelTec2 (0.5 U). Spectra of sensor with GOx (10 U, dotted line) only and CelTec2 ( $0.5 \mathrm{U}$, dashed) only are also shown. The black solid line represents the sensor only. The spectra were obtained after $1.5 \mathrm{~h}$ of incubation with both enzymes. The data was taken in PBS buffer $\mathrm{pH}=7.4\left(100 \% \mathrm{H}_{2} \mathrm{O}\right)$ at $25^{\circ} \mathrm{C}$ where $\lambda_{\text {ex }}=472$ (bandwidth 16) $\mathrm{nm}$ $7.3\left(100 \% \mathrm{H}_{2} \mathrm{O}\right)$, see ESI, Fig. S2).

To demonstrate that $\mathrm{H}_{2} \mathrm{O}_{2}$ is required for a complete turn on response, a fluorescence experiment was undertaken where CelTec2 $(0.5 \mathrm{U})$ was added to PF3-Glc and the probe was incubated for $60 \mathrm{~min}$ at $25^{\circ} \mathrm{C}$. This led to a small increase in fluorescence intensity (two-fold). Addition of $\mathrm{H}_{2} \mathrm{O}_{2}(500 \mu \mathrm{mol} / \mathrm{L})$ resulted in a large fluorescence increase (Fig. 2). The fluorescence spectra were taken one hour after $\mathrm{H}_{2} \mathrm{O}_{2}$ addition.

The selectivity of PF3-GIc was then evaluated against other $\mathrm{ROS}, \mathrm{ClO}^{-}$, peroxyl radical $(\mathrm{ROO} \bullet$ ), hydroxyl radical $(\cdot \mathrm{OH})$, superoxide $\left(\mathrm{O}_{2}^{--}\right)$and singlet oxygen $\left({ }^{1} \mathrm{O}_{2}\right)$ with and without CelTec2 (Fig. 3). In the absence of CelTec2 there is little observable response from all ROS (See ESI, Fig. S3). In the presence of CelTec2 the probe was highly selective towards $\mathrm{H}_{2} \mathrm{O}_{2}$ over all other ROS evaluated (See ESI, Fig. S4).

\section{Conclusions}

We have developed a dual enzyme activated fluorescent probe PF3-Glc for $\beta$-glc and GOx $\left(\mathrm{H}_{2} \mathrm{O}_{2}\right)$. The system can be used to monitor $\beta$-glc activity by the in-situ generation 


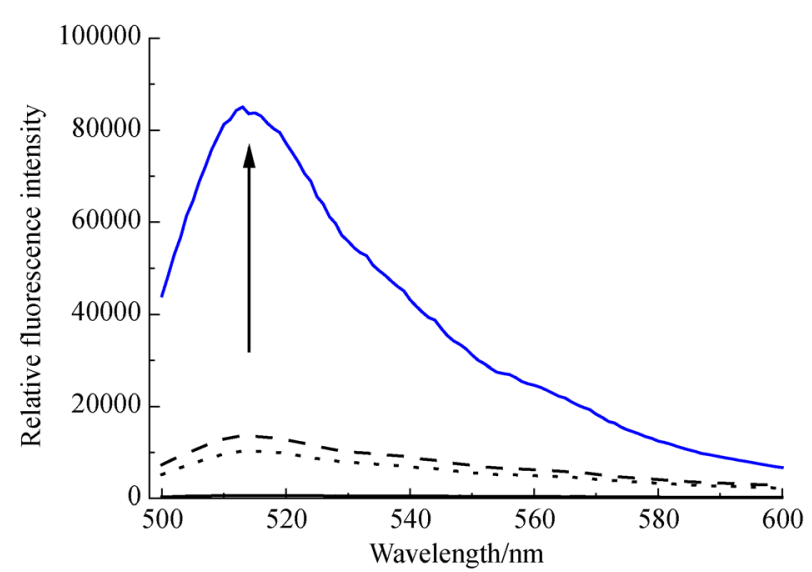

Fig. 2 Fluorescence emission spectra for PF3-Glc $(250 \mathrm{nmol} / \mathrm{L})$ in the presence of CelTec2 $(0.5 \mathrm{U})$ incubated for $30 \mathrm{~min}$ at $25^{\circ} \mathrm{C}$, prior to addition of $\mathrm{H}_{2} \mathrm{O}_{2}(0.5 \mathrm{mmol} / \mathrm{L})$ which was left to react for a further $60 \mathrm{~min}$. The data was obtained in PBS buffer, $\mathrm{pH}=7.3$ $\left(100 \% \mathrm{H}_{2} \mathrm{O}\right.$ w/w) at $25^{\circ} \mathrm{C}, \lambda_{\mathrm{ex}}=472$ (bandwidth 16$) \mathrm{nm}$. The black solid line represents the sensor only. The dotted line represents CelTec2 $(0.5 \mathrm{U})$. The dashed line represents $\mathrm{H}_{2} \mathrm{O}_{2}(0.5 \mathrm{mmol} / \mathrm{L})$

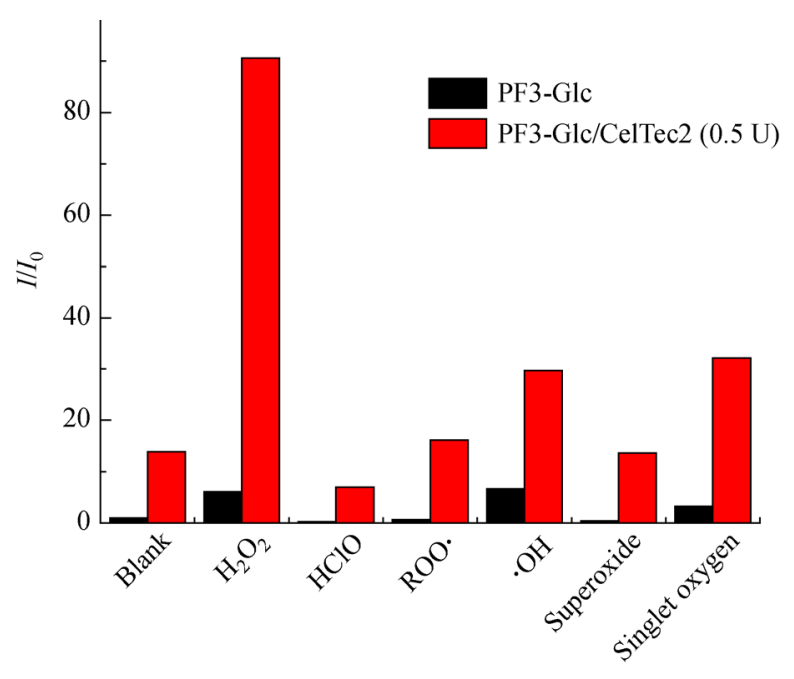

Fig. 3 Selectivity data for PF3-Glc $(250 \mathrm{nmol} / \mathrm{L})$. The sensor is incubated with CelTec2 $(0.5 \mathrm{U})$ for $1 \mathrm{~h}$, followed by the addition of ROS. Hydrogen peroxide $(0.5 \mathrm{mmol} / \mathrm{L})$ was incubated for $1 \mathrm{~h}$ before measurement. $\mathrm{HClO}^{-}(0.5 \mathrm{mmol} / \mathrm{L})$ and $\mathrm{ROO}^{-}(0.5 \mathrm{mmol} /$ L) were incubated for $30 \mathrm{~min}$ before measurement was taken. Singlet oxygen $(0.5 \mathrm{mmol} / \mathrm{L})$, superoxide $(0.5 \mathrm{mmol} / \mathrm{L})$ and $-\mathrm{OH}$ $(0.5 \mathrm{mmol} / \mathrm{L})$ were measured immediately after addition. Data shows difference in fluorescence intensity at $\lambda=510 \mathrm{~nm}$ after $1 \mathrm{~h}$. The data was taken at $\mathrm{pH}=7.3$ and $25^{\circ} \mathrm{C}$

of glucose, which is subsequently transformed into $\mathrm{H}_{2} \mathrm{O}_{2}$ by GOx and detected by PF3. PF3-Glc is an easy to prepare dual enzyme activated fluorescein based fluorescent probe. This is a simple proof of concept system and we are currently exploring how dual enzyme activation can be used to develop fluorescent sensors with enhanced selectivity and incorporating therapeutic units [18].

\begin{abstract}
Acknowledgements We would like to thank the EPSRC and the University of Bath for funding. TDJ wishes to thank the Royal Society for a Wolfson Research Merit Award. MLO, JEG and ACS thank the EPSRC for their studentships. NMR and MS Characterisation facilities were provided through the Material and Chemical Characterisation Facility $\left(\mathrm{MC}^{2}\right)$ at the University of Bath. The EPSRC UK National Mass Spectrometry Facility at Swansea University is thanked for analyses. All data supporting this study are provided as supplementary information accompanying this paper.
\end{abstract}

Electronic Supplementary Material Supplementary material is available in the online version of this article at https://doi.org/10.1007/s11705-018$1785-9$ and is accessible for authorized users.

Open Access This article is licensed under a Creative Commons Attribution 4.0 International License, which permits use, sharing, adaptation, distribution and reproduction in any medium or format, as long as you give appropriate credit to the original author(s) and the source, provide a link to the Creative Commons licence, and indicate if changes were made. The images or other third party material in this article are included in the article's Creative Commons licence, unless indicated otherwise in a credit line to the material. If material is not included in the article's Creative Commons licence and your intended use is not permitted by statutory regulation or exceeds the permitted use, you will need to obtain permission directly from the copyright holder. To view a copy of this licence, visit http://creativecommons.org/licenses/by/4.0/.

\section{References}

1. Medina R, Owen G I. Glucose transporters: Expression, regulation and cancer. Journal of Biological Research (Thessaloniki), 2002, 35 (1): 9-26

2. Iadecola C. Sugar and Alzheimer's disease: A bittersweet truth. Nature Neuroscience, 2015, 18(4): 477-478

3. An Y, Varma V R, Varma S, Casanova R, Dammer E, Pletnikova O, Chia C W, Egan J M, Ferrucci L, Troncoso J, Levey A I, Lah J, Seyfried N T, Legido-Quigley C, O'Brien R, Thambisetty M. Evidence for brain glucose dysregulation in Alzheimer's disease. Alzheimer's \& Dementia, 2018, 14(3): 318-329

4. Körschen H G, Yildiz Y, Raju D N, Schonauer S, Bönigk W, Jansen V, Kremmer E, Kaupp U B, Wachten D. The non-lysosomal $\beta$ glucosidase GBA2 is a non-integral membrane-associated protein at the endoplasmic reticulum (ER) and Golgi. Journal of Biological Chemistry, 2012, 288(5): 12-20

5. Zhou X, Huang Z, Yang H, Jiang Y, Wei W, Li Q, Mo Q, Lui J. $\beta$ Glucosidase inhibtion sensitises breast cancer to chemotherapy. Journal of Biomedicine and Pharmacotherapy, 2017, 91: 504-509

6. Wong C M, Wong K H, Chen X D. Glucose oxidase: Natural occurrence, function, properties and industrial applications. Applied Microbiology and Biotechnology, 2008, 78(6): 927-938

7. Ramanavicius A, Ryskevic N, Kausaite-Minkstimiene A, Bubniene U, Baleviciute I, Oztekin Y, Ramanaviciene A. Fluorescence study of glucose oxidase self-encapsulated within polypyrrole. Sensors and Actuators. B, Chemical, 2012, 171: 753-759

8. Chan J, Dodani S C, Chang C J. Reaction-based small-molecule fluorescent probes for chemoselective bioimaging. Nature Chem- 
istry, 2012, 4(12): 973-984

9. Wu D, Sedgwick A C, Gunnlaugsson T, Akkaya E U, Yoon J, James T D. Fluorescent chemosensors: The past, present and future. Chemical Society Reviews, 2017, 46(23): 7105-7123

10. Reeves E P, Lu H, Jacobs H L, Messina C G M, Bolsover S, Gabella G, Potma E O, Warley A, Roes J, Segal A W. Killing activity of neutrophils is mediated through activation of proteases by K Flux. Nature, 2002, 416(6878): 291-297

11. Winterbourn C C. Reconciling the chemistry and biology of reactive oxygen species. Nature Chemical Biology, 2008, 4(5): 278-286

12. Wang $\mathrm{N} \mathrm{N}$, Miller $\mathrm{C} J$, Wang $P$, Waite $\mathrm{T}$ D. Quantitative determination of trace hydrogen peroxide in the presence of sulfide using the Amplex Red/horseradish peroxidase assay. Analytica Chimica Acta, 2017, 963: 61-67

13. Quinlan C L, Perevoschikova I V, Goncalves R L S, Hey-Mogensen $\mathrm{M}$, Brand M D. The determination and analysis of site-specific rates of mitochondrial reactive oxygen species production. Methods in Enzymology, 2013, 523: 189-217

14. Wannajuk K, Jamkatoke M, Tuntulani T, Tomapatanaget B. Highly specific-glucose fluorescence sensing based on boronic anthraquinone derivatives via the GOx enzymatic reaction. Tetrahedron, 2012, 68(43): 8899-8904

15. Sedgwick A C, Han H H, Gardiner J E, Bull S D, He X P, James T D. The development of a novel AND logic based fluorescence probe for the detection of peroxynitrite and GSH. Chemical Science (Cambridge), 2018, 9(15): 3672-3676

16. Dickinson B C, Huynh C, Chang C J. A palette of fluorescent probes with varying emission colours for imaging hydrgoen peroxide signalling in living cells. Journal of the American Chemical Society, 2010, 132(16): 5906-5915

17. Dickinson B C, Chang C J. A targetable fluorescent probe for imaging hydrogen peroxide in the mitochondria of living cells. Journal of the American Chemical Society, 2008, 130(30): 96389639

18. Hong K H, Kim D I, Kwon H, Kim H J. A fluoresceinylcarbonatebased fluorescent probe for the sensitive detection of biothiols in a HEPES buffer and its cellular expression. RSC Advances, 2014, 4 (2): 978-982 